\title{
Chapter 17 \\ Japanese Beetle and Other Coleoptera \\ Feeding on Grapevines in Eastern \\ North America
}

\author{
Douglas G. Pfeiffer
}

\subsection{Introduction}

\subsubsection{Scope}

The Japanese beetle, Popillia japonica Newman, and several other coleopteran foliavores, i.e. green June beetle, Cotinus nitida (L.), rose chafer, Macrodactylus subspinosus (F.), grape rootworm, Fidia viticida Walsh, and grape flea beetle, Altica chalybea Illiger cause conspicuous foliar injury. A number of these coleopterans also cause injury to other vine parts, i.e., primary buds, berries, or roots. Although such injury may be much more economically important than the leaf injury, we will not address them here because the leaf injury arouses the greatest amount of concern. Japanese beetle is the main species to be discussed. In an earlier study (Pfeiffer et al. 1990), it was found to be the target of most insecticide sprays in Virginia vineyards, owing to its conspicuous leaf injury. Although its populations fluctuate considerably from year to year, Japanese beetle remains an important pest to be addressed by grape pest management programs in eastern North America. The thrust of this chapter is on beetles that, in at least one life stage, inflict defoliation injury on grapevines. There is one additional coleopteran that may cause economic losses, the multicolored Asian lady beetle, Harmonia axyridis (Pallas). Injury that may be inflicted to fruit by this otherwise beneficial predator is discussed by Pfeiffer et al. (Chap. 19).

\footnotetext{
D.G. Pfeiffer $(\bowtie)$

Department of Entomology, Virginia Tech., 205C Price Hall, Blacksburg,

VA 24061-0319, USA

e-mail: dgpfeiff@vt.edu
} 


\subsubsection{The Grapevine Leaf System and Fruit Ripening}

Grapevines are sometimes described as factories that transform sunlight to sugars. The process of photosynthesis produces non-structural carbohydrates, primarily sugars, that are important constituents of grape berries whether for wine production or for consumption at the table. Net photosynthesis $\left(\mathrm{P}_{\mathrm{n}}\right)$ decreases with increasing Leaf Area Loss (LAL). This not only reduces $\mathrm{P}_{n}$ for the whole leaf, resulting from reduced photosynthetic surface, but it can also decrease $\mathrm{P}_{n}$ from the remaining leaf area. This decline becomes especially steep after 20\% LAL (Boucher et al. 1987). The impact of reduced leaf area is therefore greater than expected from simple loss of leaf area. Many studies use mechanical removal of leaf area to simulate the impact of insect-induced defoliation. Care should be taken to simulate the actual injury as closely as possible. Simple removal of intact leaves (breaking the petiole from a shoot) is not a substitute for defoliation (Boucher 1986). On a broader ecological basis, evaluation of feeding impact by considering only leaf tissue removal can lead to an oversimplification of the effects of injury. This is because beetle feeding induces the production and release of plant volatiles that attract more beetles to the vine leading to further feeding, an effect not shown by simple mechanical leaf area removal.

During the development of grapevines and berry clusters, there are changes in leaf vulnerability and the source-sink relationships of sugars in the vine. Early in the season, leaves are thin and delicate. Later in the season, leaves are tougher and can tolerate more insect feeding. At that stage, they have already made important photosynthetic contributions to the vine. However, another factor mitigates the greater importance of late season photosynthesis. In the early part of the season, the main sinks for sugar production are shoots, as they are still in their growth phase. Sugar accumulation in berries is minimal at this time. After veraison, shoot growth slows down and berries become the sink for most of the sugar production. Furthermore, for red cultivars, berries begin to develop their characteristic color. Consequently, defoliation after veraison may have a greater impact on ultimate berry quality at harvest.

\subsection{Japanese Beetle}

\subsubsection{Appearance}

The adult Japanese beetle (JB), P. japonica (Scarabaeidae), is shiny green, with copper-colored elytra, with tufts of white setae arranged along the sides of the abdomen (Fig. 17.1). Male and female beetles are differentiated by an apical tibial spur on the front pair of legs that is pointed in the male and rounded in the female. The larvae are C-shaped white grubs with three pairs of legs on the thoracic segments and they are found in the root zone of grasses. The pattern of setae found on the 


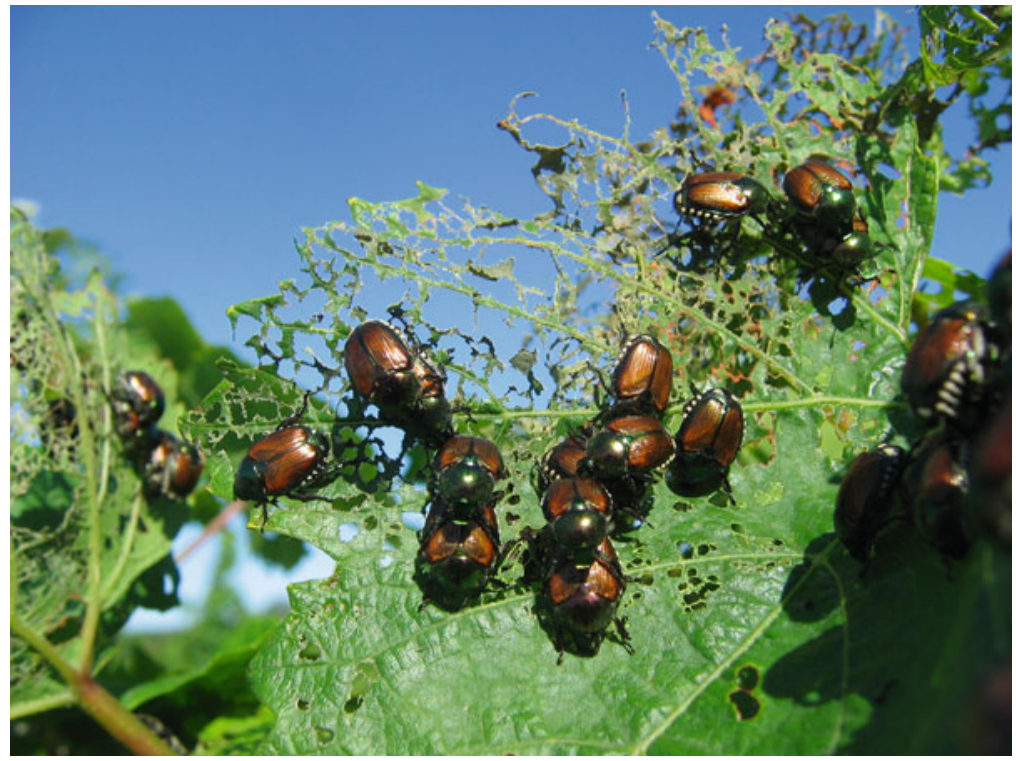

Fig. 17.1 Adult Japanese beetles with associated feeding injury to grape foliage (Photo by Rufus Isaacs)

raster (the underside of the last abdominal segment) is important in the identification of white grubs. In Japanese beetle larvae this pattern is typified by a V-shaped arrangement of setae, opening toward the hind end.

\subsubsection{Biology}

The biology of JB has been reviewed by Fleming (1972), and Potter and Held (2002). It is a native of Japan, but probably not mainland Asia (Potter and Held 2002). In the past, it had been of limited importance in Japan because of restricted habitats, and the presence of natural enemies. Recently, increased outbreaks have been associated with increases in grassy areas (Ando 1986). Other species of Popillia are also present in Asia (e.g. Popillia lewisi Arrow, Popillia uchidai Niijimi \& Kinoshita, and Popillia indigonacea Motschulsky). Japanese beetle was first found in New Jersey in 1916, but judging by its numbers it had probably been already present for about 5 years (Fleming 1968). It has now spread across all states east of the Rocky Mountains, except Florida. Climatic conditions in many parts of the world are suitable for its establishment (Potter and Held 2002). Moreover, because of human modifications of the environment through irrigation, potential areas of spread may be even greater. The adults appear in late June to early July (or early June in the southern parts of its range) and begin to feed on a wide range of plants. Males first appear slightly before females, and beetle populations peak in 
July, continuing into September. The eggs are laid in a series of ovipositional bouts, between which females return to host plants for additional feeding and mating. There is a single generation annually, but in the northern part of its range, some individuals require a second year to complete their development.

Japanese beetle is highly polyphagous, feeding on more than 300 species representing 79 different plant families, with Vitaceae among the most preferred (Potter and Held 2002). Some host plants favor higher JB reproduction than others (Ladd 1987), and the suitability of host plants appears to be dictated by secondary chemistry rather than quantitative traits, such as digestibility-reducing materials (Keathley and Potter 2008). Feeding causes the release of volatile plant compounds, which lead to the attraction of even more beetles (Loughrin et al. 1996). Usually considered as sun-loving insects, they will nevertheless spend part of their time in the shade. High levels of light and temperatures are known to enhance activity (Moore and Cole 1921) and the tendency to alight and fly toward lures (Heath et al. 2001). Companion plants have little effect (Held et al. 2003). On some hosts, beetles prefer to feed also on flowers (Held and Potter 2004), especially if the flowers are in an elevated position, but grape flowers are not very attractive. Japanese beetles prefer to lay eggs in soils with high moisture content (Allsopp et al. 1992b).

A collection of grape cultivars was rated in terms of vulnerability of JB attack by Langford and Cory (1948). Their rating system is as follows: Group 1 - Preferred cultivars (Injury very severe): Cabernet Sauvignon, Pinot Chardonnay, Baco No. 1, Delaware, Seibel 128, Seibel 1000, Seibel 1xx, Seibel 2xx, Seibel 2056, Seibel 6339, Seibel 5409, Seibel, 9110, Seibel 5279, Couderc 13, Couderc 4401, BertileSeyve 2862, Seyve-Villard 12309, Norton, Cynthiana (Norton and Cynthiana are both Vitis aestivalis Michaux, and generally considered synonymous), America, Bell, Brilliant, Manito, Rommel, Wine King, N.Y. 10839, N.Y. 1407, N.Y. 11456, N.Y. 13920, N.Y. 20159; Group 2 - Attractive cultivars (injury severe): Catawba, Delicatessen, Cloeta; Group 3 - Cultivars frequently attacked (injury moderate): Westfield (close to 'Concord') Lona, Diamond; Group 4 - Unattractive cultivars (injury light and occasional): Champanel. Most cultivars used in wine production fall into Group 1 (preferred).

An evaluation of JB preference for grape cultivars was carried out by $\mathrm{Gu}$ and Pomper (2008). A point system was assigned based on the \% of damaged leaves per vine, as well as of leaf area loss. Cultivars with $>70 \%$ incidence of injury were generally European or French hybrids, whereas those with $<70 \%$ injury were either American cultivars, or hybrids with some Vitis labrusca L. parentage. The cultivars Marquis, Reliance, Catawba, Concord Seedless, Concord, Edelweiss, and Einset showed promise for arthropod management with reduced insecticide use. It is noteworthy that Catawba was nevertheless in Group 2 (attractive) of Langford and Cory (1948).

Beetles cause a skeletonizing type of injury to grape leaves, although they may eat completely through the leaves on some cultivars. Berries are rarely attacked by Japanese beetle. However, when this happens, injury can be exacerbated by secondary feeding by the green June beetle. Adults form dense aggregations on selected 
leaves, generally feed at the top of the canopy, a typical behavior on their host plants. Leaf injury is thus greatest in the upper parts of the canopy. This stratification toward upper parts of the canopy is due to visual orientation, not some nutritional factor (Rowe and Potter 1996).

Through their feeding, JB predispose vines to further infestation (Iwabuchi and Takahashi 1983). Feeding by JB induces the release of volatile compounds that are attractive to other beetles of both sexes, and mechanically injured leaves do not show this response (Loughrin et al. 1995).

Pairs of beetles are often seen together on plant tissues. Females are often first mated as they emerge from the ground (Fleming 1972). Copulation lasts about $2 \mathrm{~min}$, but males may remain mounted for an additional $2 \mathrm{~h}$ (Barrows and Gordh 1978). Occasionally males contest for females, whereby the occupying male usually wins, unless the intruding male is significantly larger (Kruse and Switzer 2007). Eggs are fertilized by sperm from the most recent mating (Ladd 1966). During the period of adult activity, females will make repeated trips to the soil to lay eggs, and 1-4 eggs are laid at a time. Females prefer to oviposit in moist grassy areas. The eggs hatch in about 2 weeks, and then the larvae feed on grass roots until the onset of cold weather, when they descend several centimeters deep in the soil. In southern parts of the range, or when winters are mild, larvae may not leave the root zone. In spring, the larvae return to the root zone to resume feeding until they begin to pupate in May.

There are reports that JB infestations are most severe in the Mid-Atlantic States, where there are large acreages of larval habitats (pastures) adjacent to vineyards, the preferred adult food. This combination is very favorable for the growth of JB populations (Régnière et al. 1983). In Massachusetts, adults are active from midJuly to mid-August, peaking in late July. In a Massachusetts study, the majority of adults were not reproductively mature until late August, and eggs were recovered from turf in early September (Vittum 1986). In this northern part of the range, at least a portion of the population requires 2 years to complete its development. Infestations vary widely from year to year. This is partly influenced by seasonal rainfall patterns, because the eggs are susceptible to desiccation in dry soil. Rainfall should be at least $250 \mathrm{~mm}$ and distributed uniformly over the summer for good survival (Fleming 1970, 1972).

\subsubsection{Impact of Japanese Beetle Feeding}

A survey of grape grower practices in Virginia in the mid-1980s revealed that most of the insecticide sprays in Virginia vineyards were targeted against JB, because of its conspicuous feeding injury (Pfeiffer et al. 1990). Consequently, a study was initiated to determine the effects of this feeding on berry yield and quality (Boucher and Pfeiffer 1989). Four feeding treatments were compared on the French hybrid 'Seyval Blanc' in the upper Shenandoah Valley: a natural unprotected plot, a controlled plot 
where beetle feeding was prevented, and two caged plots where high numbers of beetles were contained on vines (1) from the beginning of beetle activity to veraison, and (2) from veraison to harvest. The natural infestation did not result in any significant reduction in berry quality, yield or vine growth, despite greater leaf area loss than in the control (6.5\% versus $3 \%$ leaf area loss, respectively). Intensive feeding by JB after veraison caused the most severe effects on berry quality. These vines had $11 \%$ leaf area loss when averaged over the whole vine (initial visual impact of feeding may be misleading because feeding is more intense on the upper leaves). This loss occurred in less than one half the time relative to natural feeding, about 3 weeks compared with 6 weeks, respectively.

Although established vines can tolerate injury caused by JB feeding, young vines can be totally defoliated and should be protected more rigorously, especially when grown in tubes (i.e. plastic cylinders often placed around newly planted vine trunks, intended to provide protection). Hence, vines are most vulnerable when young, and also after veraison once they are mature.

A Michigan study compared the effects of feeding by rose chafer and JB on berry quality of $V$. labrusca 'Niagara' vines (Mercader and Isaacs 2003). These beetles attack vineyards in early and mid-season, respectively. Feeding around bloom by rose chafer resulted in a loss of less than $1 \%$ LAL. Feeding during veraison by JB resulted in about $7 \%$ LAL, somewhat lower than the levels determined by Boucher and Pfeiffer (1989). These levels of feeding caused no differences in vine growth parameters. That study also included an artificial leaf area removal experiment, removing up to $30 \%$ of each fully expanded leaf at either bloom or veraison. While this level of defoliation caused reduced trunk diameters measured at veraison, there were no differences among treatments by the time of leaf abscission in the fall. Berry parameters were not evaluated in that study. Young vines were able to tolerate levels of feeding exceeding those imposed by population levels used in the study.

A study conducted in Kentucky showed that there are important cultivarspecific differences in sensitivity of vines to JB feeding (Hammons et al. 2010). The study compared six cultivars: two American cultivars (Vitis labrusca L. 'Concord', Vitis aestivalis Michaux 'Norton'), two European cultivars (Vitis vinifera L. 'Cabernet Franc', 'Cabernet Sauvignon'), and two French-American hybrids (V. vinifera $\times$ Vitis riparia Michaux 'Chambourcin' and Vitis sp., interspecific hybrid 'Frontenac'). The percent defoliation levels noted for the 2 years of the study were: 'Concord' $=7,5$; 'Cabernet franc' $=39,35$; 'Frontenac' = 38, 37; 'Norton' =44, 44; 'Chambourcin' = 46, 43; 'Cabernet Sauvignon' =48, 38. With its thicker epidermis, 'Concord' had markedly less injury than all the other cultivars, which were very close together in terms of defoliation. 'Concord' is in Group 3 of Langford and Cory (1948), while all of the other cultivars fall in Group 1 (preferred). Hammons et al. (2010) adjusted defoliation levels by using different pesticide regimes: carbaryl every 7 versus 14 days, or no insecticide. 'Norton' exhibited reduced vine growth, delayed synthesis of sugars, and reduced yield, while 'Concord' showed little effect. Insecticides to protect 'Concord' grapes from JB offered no benefit for vine growth or cluster yield and quality. 


\subsubsection{Pheromone Biology and Monitoring}

Trapping for JB began soon after its establishment in the United States. Much research attention was given to this area for several decades, not only to determine phenology and to time control measures, but to follow the spread of this invasive species. In the 1930s, traps baited with a 1:10 blend of eugenol and geraniol were used with or without phenethyl alcohol (Britton and Johnson 1938).

In 1970, evidence for a sex pheromone in JB was discovered (Ladd 1970), and there were attempts to use adult females as lures (Goonewardene et al. 1973). Male extract caused greater electroantennogram response than did a female extract (Adler and Jacobson 1971). The sex pheromone was eventually described as $(R, Z)-5-1$ decenyl)-dihydro-2(3H)-furanone (Doolittle et al. 1980) and given the name Japonilure. The $R$ enantiomer is required for attraction and contamination with small amounts of the $S$ enantiomer inhibits attraction. This is part of a reproductive isolating mechanism used by the sympatric scarab Anomala osakana Sawada in its native Japan because this species uses $S$-japonilure as its pheromone (Leal 1998).

In more recent years, a lure containing PEP (phenethyl propionate) became standard for monitoring JB. Adding eugenol to PEP enhanced captures, as did addition of Japonilure, the sex pheromone (Ladd et al. 1981; Ladd 1986). The sex pheromone Japonilure is more effective when used with plant volatiles than when used alone (Klein et al. 1981; Allsopp et al. 1992a).

In a study to evaluate a visual component, white traps were determined to be the most attractive, followed by yellow. Shielding traps to limit emission of attractants by trapped virgin females enhanced trap captures by keeping attracted beetles from accumulating on the outside of the canister (Klein et al. 1973). While bag type traps sometimes lose efficiency because of beetles escaping through drain apertures, the larger volume of such traps is useful during periods of high beetle activity (Klostermeyer 1985). Agronomic habitats such as fields of corn and soybean increased trap catches (Hamilton et al. 2007).

Beetle captures increase if trapped beetles are removed each day before decomposition occurs. Traps are highly attractive and they may become filled with beetles quickly and may need to be serviced frequently in times of high beetle activity. However, traps do not provide control of JB, possibly because more beetles are attracted into the area than are collected. In fact, defoliation near traps is sometimes greater than where no traps are present (Gordon and Potter 1986). If traps are to be used as part of a JB management program, they should not be placed near the vines to be protected. Instead, they should be placed some distance away, upwind of the vineyard, so that attractant volatiles will drift over the crop, allowing beetles to be attracted upwind to the traps while minimizing attraction of additional beetles into the site.

Traps are most effective for monitoring, including detection of isolated populations. Use of JB traps aided the successful eradication of isolated populations of this pest in California (Alm et al. 1996). Some of the other species of Popillia in Asia (e.g., P. lewisi, P. uchidai and P. indigonacea) respond to lures for JB, although there are some specific differences (Klein and Edwards 1989; Reed et al. 1991). 


\subsubsection{Biological Control}

Biological control of JB was reviewed by Fleming (1968). Explorations in the native range of the beetle began soon after its establishment in the eastern United States. Two entomologists searched in Japan and other parts of Asia for several years beginning in 1920 (Fleming 1968). Fleming (1968) provided a list of parasites and predators, including some that were released but were not known to have become established. The most important species will be discussed here.

Tiphia vernalis Rohwer (Tiphiidae) emerges in the spring, and overwinters in the pupal stage. Tiphia popilliavora Rohwer (Tiphiidae) emerges in summer and fall, and overwinters in the larval stage. Both species are specialists on JB in Japan. Frass kairomones help orient Tiphia to its hosts (Rogers and Potter 2002). Both species were released in New Jersey, T. vernalis beginning in 1921, and T. popilliavora in 1925. Both Tiphia species were released in mid-1930s in Connecticut, where they successfully established (Britton and Johnson 1938). Tiphia vernalis was considered to be the most effective of the introduced parasitoids. When adult wasps are active in May, the grubs are in the third instar, the primary target of ovipositing female Tiphia. Furthermore, there was a strong density dependent numerical response, with \% parasitization increasing with high JB density. Tiphia vernalis is now found in every county of Connecticut, after the state introduced this natural enemy, including at two sites where it was never released, reflecting natural spread (Ramoutar and Legrand 2007).

Three geographical strains of T. popilliavora were released from Japan, Korea and China (Fleming 1968). The Japanese strain flies in August and September. For the first half of its flight, most grubs are in first and second instars, not preferred by the hunting wasps. Later in the flight, most JB are in second and third instars. The third instar is preferred by the parasitoid. The Korean strain is active a little later in September, when most grubs are in the third instar. Hence, this strain is more closely matched to JB phenology. Insecticides have inconsistent negative effects on parasitism by T. vernalis. Parasitism was greater when an insecticide was combined with the parasitoids (Oliver et al. 2005). Nevertheless, bifenthrin, chlorpyrifos, and imidacloprid lowered survival of adult $T$. vernalis, while halofenozide had a minimal effect (Oliver et al. 2006). Isophenphos and diazinon decreased predation by ants on JB immature stages, whereas imidacloprid and a halofenozide treatment had no effect (Zenger and Gibb 2001a). The Tiphia species are now widely established, but sporadic in occurrence.

A univoltine tachinid, Istocheta aldrichi (Mesnil) (formerly known as Hyperecteina aldrichi), parasitizes adult beetles. Eggs are laid on the pronotum of mating female JB. About 36-48 h after eggs are laid, larvae drill downward into the body cavity where internal organs are consumed, killing the beetle usually within 5 days (Fleming 1968). In Japan it is a specialist predator of JB (Fleming 1968). In the United States, it is not well synchronized with JB and only attacks the earliest-emerging adults, missing the peak of JB activity. Istocheta aldrichi was first released in New Jersey in 
1922, and over nearly 30 years, in more than 50 sites in 12 states, with successful establishment occurring in most (Fleming 1968). Another tachinid from Japan, Centeter cinerea Aldrich, was released but its establishment is unknown (Britton and Johnson 1938), and it was not mentioned by Fleming (1968). This species was thought to be the most successful in northern parts of the range of JB (King 1931).

Ants may also be a source of natural mortality for JB eggs (López and Potter 2000). While Fleming (1968) believed that ant predation would usually impose insufficient mortality on JB, pesticide impact studies have shown generalist predators to be a significant source of natural mortality. Ant-induced mortality of eggs has been reported to exceed $80 \%$ (Zenger and Gibb 2001b).

Japanese beetle larvae are subject to attacks by a bacterium, Paenibacillus (formerly Bacillus) popilliae (Dutky), causing milky disease. After sporulation, the hemolymph turns milky white, hence the name of the disease. It was found naturally infecting JB grubs in NJ in 1933 (Fleming 1968). A second bacterium, Paenibacillus lentimorbus (Dutky), was also found in the grubs. These pathogens are thought to be natural mortality agents for JB only. However, other scarab species are infected by different host races of $P$. popillae. These races cause mortality mainly in the scarab species in which they were collected (Fleming 1968). There have been reports in recent years of lower efficacy of commercial preparations of $P$. popilliae (Dunbar and Beard 1975), including contamination of preparations with nonpathogenic Bacillus species (Stahly and Klein 1992). In fact, preparations known to contain $P$. popilliae led to incomplete control. Therefore, milky disease was considered as one of a complex of agents that could help suppress JB populations, but not as a stand-alone control tactic. Infection levels of larvae in a Connecticut survey were only 3.5\% (Hanula and Andreadis 1988). In addition to quality control problems, there are also environmental variables that may slow the development of efficacious soil titers of bacteria. Soil temperatures of $21^{\circ} \mathrm{C}$ are needed for bacterial development, and the number of weeks above $21^{\circ} \mathrm{C}$ will affect the time required by the bacteria to become effective (Fleming 1968). This biological control agent can be used in grassy areas with large larval populations, but it is ineffective against adults entering the vineyard. Adults are capable of flying great distances and may invade the vineyard from untreated areas. Consequently this organism is more important in turf management of JB than in fruit systems.

Entomopathogenic nematodes attack JB (Fleming 1968; Koppenhöfer et al. 2000). One of the most important species was reported to be the entomogenous nematode Steinernema (Formerly Neoaplectana) glaseri (Steiner) (Fleming 1968). This species was released over wide areas, but most of these were later deemed unsuccessful, owing either to low tolerance of cold temperatures (this nematode was found only in southern New Jersey), or to the elimination of the bacterial symbionts in the rearing procedures. Symbionts are needed to overcome host defenses, and this became known only more recently (Gaugler et al. 1992). In some cases there are differences in susceptibility, but in others there is a uniform response (Koppenhöfer and Fuzy 2004). Root cues enhance infection by S. glaseri and Heterorhabditis bacteriophora 
Poinar (Wang and Gaugler 1998). Steinernema glaseri and H. bacteriophora were the most effective nematodes against JB (Wang et al. 1994). The Japanese beetle showed a strong encapsulation defense against all injected nematodes except $S$. glaseri. Of the three nematode species (Steinernema carpocapsae (Weiser), S. scapterisci n. sp., and $H$. bacteriophora) that induced the encapsulation response, $H$. bacteriophora and $S$. carpocapsae were able to overcome the response, but S. scapterisci was not. Steinernema glaseri was also found to be the most effective nematode (Alm et al. 1992), although a high level of control was not consistently attained. Steinernema glaseri was the most common nematode collected in North Carolina (Régnière and Brooks 1978). In a study in The Azores, S. glaseri and H. bacteriophora caused complete mortality of larvae. Steinernema carpocapsae caused almost $60 \%$ mortality. It was also reported to be an inferior control agent for JB by Georgis and Gaugler (1991). The entomopathogenic nematodes H. bacteriophora HP88 and H. marelatus Liu \& Berry performed poorly to moderately (Mannion et al. 2001). Elsewhere, H. marelatus has outperformed insecticides in other trials (Mannion et al. 2000). Irrigation immediately before and after application of entomopathogenic nematodes improves the level and consistency of control (Downing 1994).

Strains of nematodes with more effective host detection ability have been identified. These strains have increased ability to detect $\mathrm{CO}_{2}$, and hence non-diapausing larvae, but their ability to find diapausing JB larvae has not improved (Gaugler and Campbell 1991). When these nematodes are widespread they may protect turf from white grub feeding and decrease population pressure. However, they are usually insufficient to protect grapevines from immigrating adult beetles.

Larvae of JB have some defense against entomopathogenic nematodes. Through grooming by rubbing with their legs or raster, and by host encapsulation, successful infection rates are decreased (Gaugler et al. 1994; Wang et al. 1995). There can also be avoidance behavior, with JB grubs moving to sections of grass plantings not treated with H. bacteriophora (Schroeder et al. 1993; Gaugler et al. 1994).

Other pathogens have been evaluated for JB management. In a survey for white grub pathogens in Connecticut (Hanula and Andreadis 1988), four of the seven species of scarabs encountered in 49 sites were exotics and made up $91 \%$ of the samples. Cephaline gregarines were the most (42 sites) widely distributed pathogens. The microsporidium fungus Ovavesicula popilliae n. g., n. sp. was found in JB from 34 sites. Overall, 25\% of the larvae were infected, but prevalence was $80-90 \%$ in some locations. Described from JB (Andreadis and Hanula 1987), this pathogen lowers fecundity of JB by 50\% (Hanula 1990). The fungus Metarhizium anisopliae (Metschnikoff) Sorokin infected about 1.2\%. In a Michigan study, some parasitoids and parasites common in more eastern States were uncommon. The most common parasite was a cephaline gregarine (Stictospora sp.) (Cappaert and Smitley 2002), described as S. villani n. sp. (Hays et al. 2004). Dutky and Gooden (1952) described the rickettsia Coxiella popilliae (now Ricketsiella popilliae (Dutky and Gooden) Philip), that causes a blue disease in larvae. Though not present in all survey sites, it was common in some and thought to have potential as a microbial control agent. Koppenhöfer et al. (2000) reported Bacillus thuringiensis Berliner var. japonensis 
strain Buibui, to cause limited to high mortality. According to Mannion et al. (2001) this strain of B. thuringiensis, and Beauveria bassiana (Balsamo) Vuillemin caused poor to moderate mortality.

Some vertebrates also feed on JB, either in the adult or larval stages. Fleming (1968) listed several species of birds whose stomach contents contained remains of JB. Common grackle was the most important avian predator of JB adults, followed by meadowlark, European starling, northern cardinal and catbird. Among mammals, the most important predator was the skunk, which digs below the soil surface for grubs. The disruption of turf by hunting skunks poses a secondary problem resulting from larval presence, mainly in golf courses and other high-value turf. Hogs, moles and short-tailed shrews were other mammalian predators of JB larvae (Fleming 1968). Vertebrate predators are rarely able to make a significant impact on JB numbers in an area.

\subsubsection{Cultural Control}

In a study of ovipositional preferences, Wood et al. (2009) suggested that planting hybrid Bermudagrass may decrease JB oviposition and the resulting infestations of white grubs in high value turf. Larval densities can be reduced by planting nongrass cover crops in perennial fruit plantings (Szendrei et al. 2005; Szendrei and Isaacs 2006), but this may also lead to increased feeding by the adults. Withholding irrigation during peak JB flight may successfully reduce larval populations (Potter et al. 1996). Beetles move more slowly in strip cropped soybean (Bohlen and Barrett 1990), but in this case the dwarf sorghum plants used as interplants were about the same height as the soybean plants. Unfortunately, this would be hard to implement in vineyard settings.

The use of geranium as a companion plant to protect against JB has also been examined. Zonal geranium (Pelargonium $\mathrm{x}$ hortorum) was reported to cause narcotic/paralytic effects in JB by Fleming (1972). This was confirmed by Potter and Held (1999), who reported that naïve beetles prefer geranium petals over the otherwise attractive linden leaves, undergoing a temporary period of paralysis thereafter. The paralysis ensued rapidly and lasted $12-16 \mathrm{~h}$. The preference for geranium petals was retained even after several bouts of paralysis resulting from their consumption. Such relative comparisons must be done for different crops. For example, geranium petals are less competitive with leaves of raspberry (Maxey et al. 2009); companion or trap planting may be less likely in the raspberry system than in grape, and this warrants further investigation.

Endophyte-infected grasses have resistance against some phytophagous insects because of toxic alkaloids. While the alkaloids in endophyte-enhanced grasses are mainly active against defoliators of grasses (alkaloids are absent in roots (Breen 1994)), there is some evidence for a negative effect of such grasses on JB grubs (Potter et al. 1992). 


\subsubsection{Chemical Control}

\subsubsection{Adult Control}

Carbamates and organophosphates have long been employed against JB. Carbaryl has been a standard insecticide causing high mortality and rapid knockdown (Lockwood et al. 2010). However it is detrimental to beneficial arthropods and may induce secondary pest outbreaks. Phosmet is one of the few organophosphates currently registered for vineyards in the United States (Wise et al. 2009), and is highly active on JB. Pyrethroids have been reported to be more effective than carbaryl (Baumler and Potter 2007). However, they are even more toxic to predators and parasitoids, and have been linked with outbreaks of grape mealybug in vineyards, a vector of grapevine leafroll virus.

Neonicotinoids are a newer class of insecticide that are used on a wide range of cropping systems. Imidacloprid has both lethal and sublethal effects. Direct mortality is most evident when berries and leaf surface residues are high, thereafter sublethal feeding deterrent effects become evident (Wise et al. 2007). Acetamiprid is moderately toxic to JB (Williams and Fickle 2007, 2008). Thiamethoxam provides some repellent activity for JB, contributing to efficacy of a pre-mix blend sold under the trade name Voliam Flexi ${ }^{\circledR}$, where defoliation was decreased without a significant reduction in JB numbers (Wise et al. 2009). Other new chemical classes have representatives that can be used for JB control, including indoxacarb and chlorantraniliprole (Williams and Fickle 2007, 2008).

\section{Organic Adulticides}

Particle film technology such as kaolin successfully reduced JB adults and their damage in peach (Lalancette et al. 2005). A disadvantage of this product is the high use rate recommended, i.e. $28-56 \mathrm{~kg} / \mathrm{ha}$ per application. Furthermore, the label (CDMS 2010) warns that for wine grapes: 'Harvest parameters can be altered and maturity can be delayed especially in white wine varieties. Harvest parameters have to be closely monitored to determine optimal time to harvest. Changes in harvest parameters can affect final taste. Wine grapes sprayed up to veraison will have minimal adherence to berries. Applications after veraison will adhere more on grape berries.' An advantage is that this product also controls some diseases, and protects against sunburn in hot regions of production.

\section{Natural Insecticides}

Azadirachtin is an extract from the neem tree, originally from India and Africa. It has a complex mode of action and it acts as an insect growth regulator (inhibiting biosynthesis of ecdysone) and as a repellent. As an insect growth regulator azadirachtin has no effect on adult JB. Ladd et al. (1978) showed that extracts of neem seeds were highly repellent to adult JB, protecting sassafras and soybean 
leaves almost completely from JB feeding. Some commercial formulations of azadirachtin also performed well against adults on peach (Lalancette et al. 2005). In Florida, studies showed azadirachtin to cause low morbidity and mortality against adult JB (Vitullo and Sadof 2007a, b). Those workers found that at low JB pressure the use of repeated azadirachtin sprays exerted some control, but a single application did not. Some effect was seen by removing beetle-marked plant tissue, but this was not enough to be of importance. A commercial azadirachtin formulation (AzaDirect $^{\circledR}$ ) has been recommended for JB (Lockwood et al. 2010), but it was found ineffective to control JB on primocane-bearing raspberries by Maxey et al. (2008). A second formulation $\left(\mathrm{Neemix}^{\circledR}\right)$, applied alone also did not differ from untreated plots. The second formulation, when combined with a clarified hydrophobic extract of neem oil (Trilogy®), was effective (L. M. Maxey and D. G. Pfeiffer, unpubl. data). JB was found to habituate to residues of azadirachtin (Held et al. 2001). However, those authors felt that such habituation would have little significance in the field because of the great mobility of adult beetles among a wide host range.

\subsubsection{Larval Control}

Larval control is more important in turf management of JB than in fruit systems. However, there may be a role for larval management in overall suppression of beetle populations in an area. This may be practical in an area where high cash value turf (i.e., golf courses or residential lawns) are near vineyards, but less so when pasture or range are nearby. Both types of habitats abound in the eastern US. Imidacloprid, thiamethoxam, and halofenozide performed well against white grubs in turf (Cowles et al. 1999). Soil type can also affect the relative efficacy of soil insecticides. Some insecticides can decrease the efficacy of nematode control (Cowles and Villani 1994). Conversely, synergism has been reported between neonicotinoids and entomopathogenic nematodes used together to control JB larvae (Koppenhöfer and Kaya 1998). Azadirachtin completely interrupted normal development of larvae (Ladd et al. 1984). While resistance is not often reported against JB, possibly because of the large population of unsprayed beetles with such a wide host range, resistance to cyclodiene insecticides was reported after repeated use of this class of insecticides to control larvae in turf (Niemczyk and Lawrence 1973).

\subsection{Green June Beetle}

\subsubsection{Appearance}

The adult green June beetle (GJB), C. nitida (Scarabaeidae), is about $25 \mathrm{~mm}$ long and $13 \mathrm{~mm}$ wide, and flat on the top. Beetles are dull velvety green above, with deep yellow to bronze margins and metallic green below (Fig. 17.2). Grubs are grayish white and considerably larger than JB grubs, less C-shaped than other white grubs, though when disturbed they will coil tightly. 
Fig. 17.2 Green June beetle adult

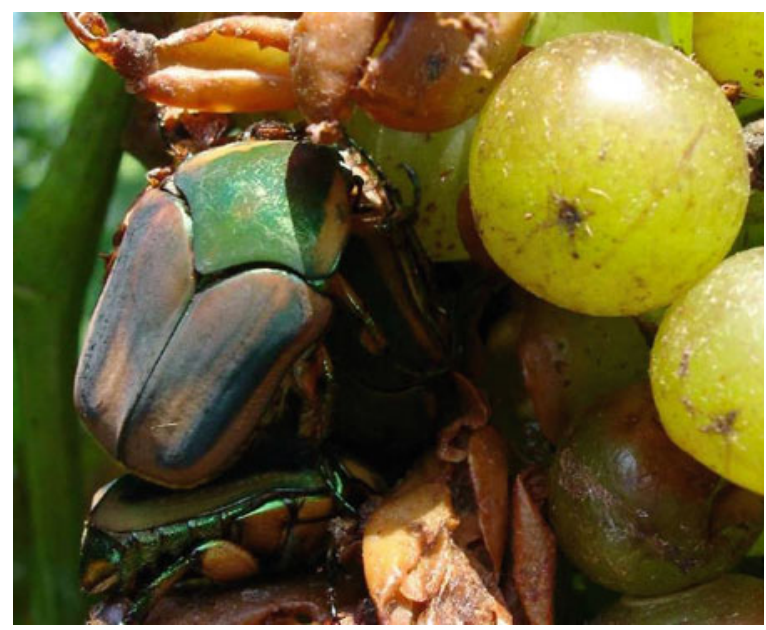

\subsubsection{Biology}

The green June beetle has a similar life history to JB and although differences in injury to grapevines exist, there are some similarities such as causing mainly skeletonizing injury to foliage. Adult GJB feed on the foliage of many shrubs and trees and will attack most tree fruits and berries. There is one generation per year. Grubs overwinter up to $30 \mathrm{~cm}$ below the soil surface. They gradually make their way close to the surface during the spring and feed mainly on rich organic matter such as decaying plant material, and to a lesser degree on roots. Larvae may leave their protected sites and crawl on their backs to establish a new site elsewhere. By May, grubs have pupated. Adults emerge in early July and August. Females oviposit in soil with decaying vegetation. Adults feed on petioles, leaves and fruit, and a single beetle can cause significant damage. Adults are often found in groups and take large chunks from the fruit.

Adult GJB are unable to break through the skin of grape berries. However, JB or other factors such as hail, yellowjacket injury may break the berry skin and allow GJB to feed (Hammons et al. 2008). A study of head space volatiles of fermenting apples led to development of a 5-component blend that was equally or more attractive than the natural material (Johnson et al. 2009). Males and females feeding on ripe fruit emit an aggregation pheromone (Domek and Johnson 1988) that is produced by yeasts in the diet or digestive tract of the beetles (Domek and Johnson 1990). More males are attracted to feeding females than to males, but females are attracted equally to either sex. Three to six days are required after feeding before the pheromone is produced (Johnson and Vishniac 1991). Adult beetles lack yeasts at the time of emergence but they acquire the microflora as they feed (Vishniac and Johnson 1990). There is also evidence for a sex pheromone (Domek and Johnson 1987). Before coupling for mating, both sexes cast about in a zigzag pattern, until 
the male drops on the female, hooking front tarsi at the leading edge of the female pronotum (Patton 1956).

In a search for an attractant for this species, molasses was found to be more attractive than a variety of other candidate feeding attractants (Wylie 1969). Green June beetle adults are also attracted to isopropanol bait (Landolt 1990). Once mated, females lay eggs in rich soils (Chittenden and Fink 1922).

\subsubsection{Importance of Injury}

Fruit injury is more common than that caused by JB, and it is more likely to occur when populations are large. Most injury to grapes is seen in late July and August, and unlike injury from JB, it can occur on both unripe and ripening fruit.

\subsubsection{Monitoring}

Traps used for JB are somewhat effective for GJB, but are only used to indicate the initial adult emergence. Direct fruit counts by examining berry clusters on the vine are the most effective way of assessing damage. Since feeding may be unevenly distributed, every effort should be made to collect a representative sample before deciding on control measures. A treatment is justified if feeding exceeds $1 \%$ of clusters examined. Adults may be monitored by quietly jarring several cordons along the vine row, and counting how many beetles fly off.

\subsubsection{Biological Control}

In a study in Norfolk, Virginia (Chittenden and Fink 1922), two sarcophagid parasites were reared from GJB. Sarcophaga utilis Aldrich, was reared from adults, and S. (Helicobia) helicis Townsend was reared from both pupae and adults. The latter species is half the size of $S$. utilis, but more common. A digger wasp, Discolia dubia Say, was also collected. Several other insect predators were listed in that study. The fungal pathogen $M$. anisopliae infected GJB, and several birds were found to be predatory.

\subsubsection{Chemical Control}

Generally the same insecticides are recommended for GJB as for JB, although GJB may be more difficult to control. Carbaryl has been a standard material used for control of both species. Thiamethoxam, imidacloprid, chlorantraniliprole, deltamethrin, 
beta-cyfluthrin, clothianidin, fenpropathrin, and carbaryl all provided a high degree of control. A blend of $10 \%$ rosemary oil with $2 \%$ peppermint oil, metaflumizone, and a plant oil extract from Chenopodium ambrosioides (Requiem ${ }^{\circledR}$ ) have all provided moderate control. The Aza-Direct formulation of azadirachtin provided inadequate control (Johnson and Lewis 2008, 2009).

\subsection{Rose Chafer}

\subsubsection{Appearance}

The adult rose chafer (RC), M. subspinosus (Scarabaeidae), is $13 \mathrm{~mm}$ long, with a straw colored body, reddish brown head and legs (Fig. 17.3). The legs bear long spines. The larva is about $19 \mathrm{~mm}$ long (McCleod and Williams 1990).

\subsubsection{Biology}

The rose chafer emerges in late May or early June in the southern part of its range, and mid-June in the north. It ranges from Canada and Minnesota to Virginia and Tennessee, west to Oklahoma and Colorado. It is most destructive from southern

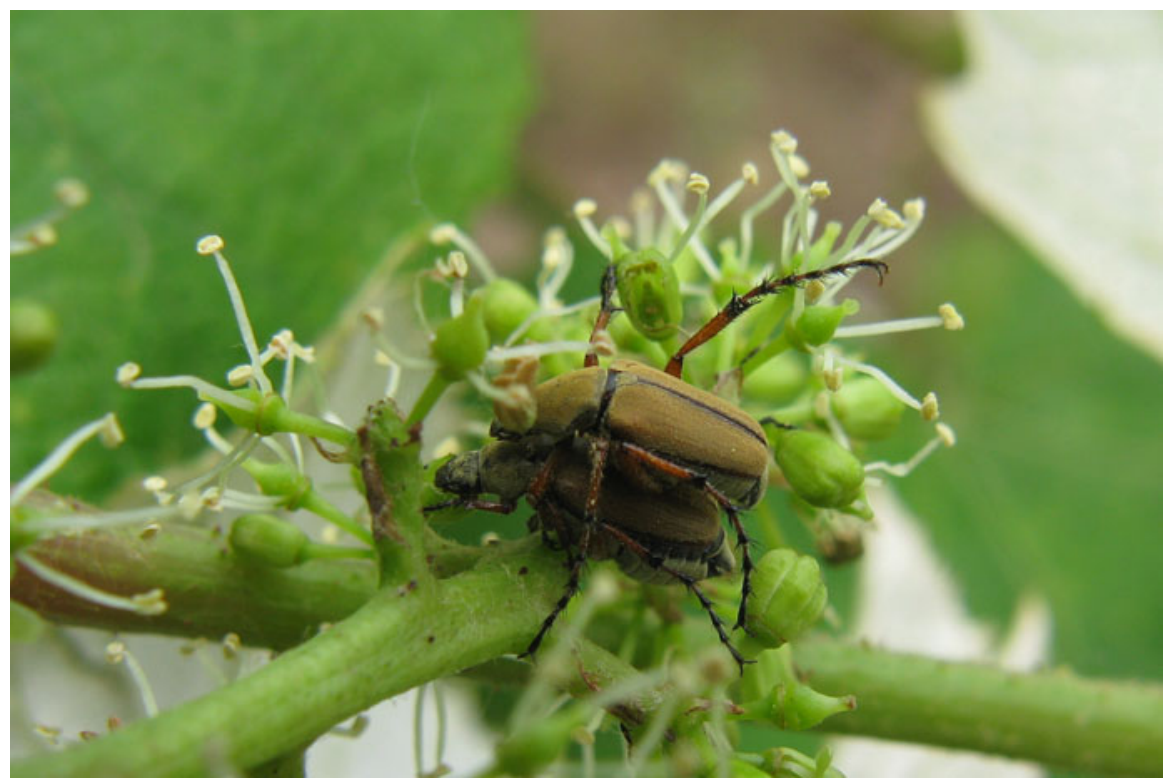

Fig. 17.3 Rose chafer adults (Photo by Rufus Isaacs) 
New England to the mid-Atlantic states. Rose chafer is polyphagous, but rose and grapevines are among the most vulnerable hosts, where it feeds on blossoms, leaves and berries. Adults are active from 4-6 weeks. Females lay 24-36 eggs singly, several $\mathrm{cm}$ below the soil surface. Eggs hatch in 2-3 weeks, feeding on grass roots until cold weather, when they descend below the frost line (Chittenden and Quaintance 1916). Eggs are laid preferentially in soils with high moisture content (Allsopp et al. 1992b).

\subsubsection{Monitoring}

The same attractants for JB are effective for rose chafer. However, addition of eugenol does not increase trap captures of RC (Williams and Miller 1982). Caproic and valeric acids have been reported as potential attractants (Williams et al. 1982). Monitoring should take place during grape bloom, since the adults will feed on clusters at that time and in the following few weeks.

\subsubsection{Cultural Control}

Site selection affects vulnerability of grapevines to RC. This species is mainly a problem in vineyards on sandy soils (McCleod and Williams 1990).

\subsubsection{Chemical Control}

With the regulatory demise of chlorinated hydrocarbon and organophosphate insecticides, carbaryl is now a standard recommendation (Lockwood et al. 2010). Acetamiprid is also effective and is less disruptive to biological control. Phosmet and fenpropathrin may also be recommended (Bordelon et al. 2011).

\subsection{Grape Flea Beetle}

\subsubsection{Appearance}

The adult grape flea beetle (GFB), A. chalybea (Chrysomelidae), is a metallic bluegreen beetle and is almost $5 \mathrm{~mm}$ long (Fig. 17.4). Eggs are light yellow and are laid in masses. They hatch in a few days and larvae feed on grape leaves for 3-4 weeks. Larvae are brown with black spots, and reach a length of $10 \mathrm{~mm}$ (Fig. 17.5). 


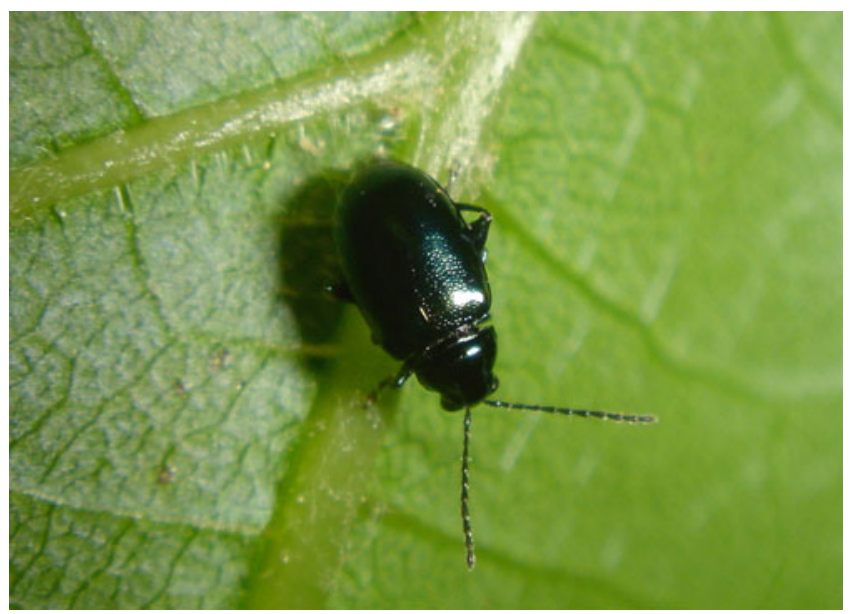

Fig. 17.4 Grape flea beetle adult

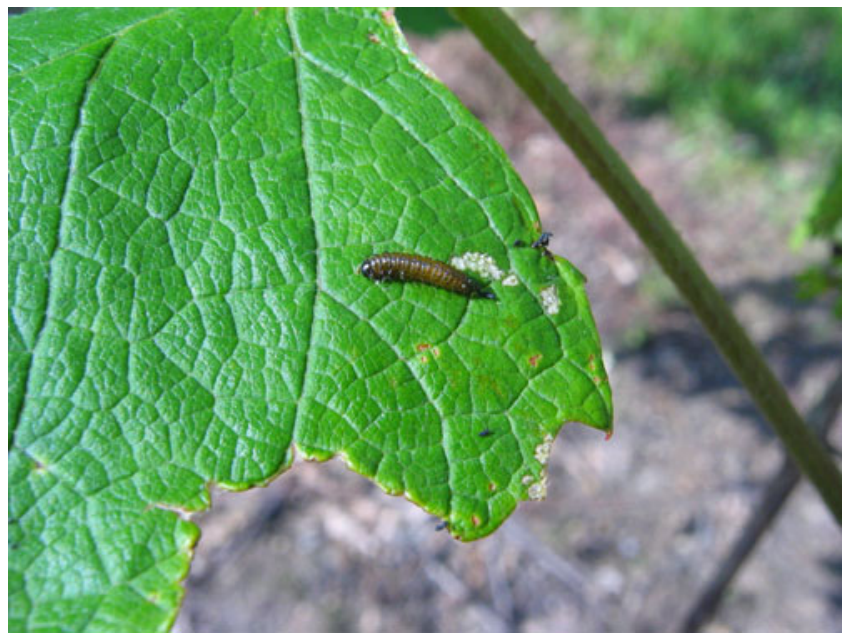

Fig. 17.5 Grape flea beetle larva and associated injury to grape foliage (Photo by Rufus Isaacs)

\subsubsection{Biology}

Adult grape flea beetles overwinter in debris in and near the vineyard. They become active early in spring and lay eggs in cracks in the bark, at bases of buds, between bud scales, and on leaves. After feeding on foliage, mature larvae drop to the ground and pupate in an earthen chamber. Adults emerge 1-2 weeks later in July and August. They feed on grape foliage for the rest of the summer causing little damage. In the fall they seek protected places in which to overwinter. In addition to wild and cultivated grapes, grape flea beetles feed on Virginia creeper. The grape flea beetle is more 
common in neglected vineyards, but some eastern commercial growers consider this species their main insect pest, especially in vineyard rows near deciduous forest.

\subsubsection{Importance in Injury}

Larval feeding damage consists of characteristic chain-like feeding marks on leaves. Individual leaves may become very ragged in appearance, but real effect on vines or crop is rare. The damage by adult grape flea beetles is more important. The beetles eat holes into the sides of buds and gouge out the contents as the buds swell. They also feed on the unfolding leaves. Once the young shoots have grown past $5-12 \mathrm{~cm}$, they are no longer vulnerable.

This pest may escape accurate identification because the injury caused by adults can easily be mistaken for that caused by climbing cutworms. Injury by the latter is more likely to be ragged in appearance, though there is an overlap in appearance. The grape flea beetle injury is heaviest near wooded edges, whereas cutworm injury may be spread throughout the block. Injury to the leaves by larvae may be confused with that caused by adults of grape rootworm. Proper identification is of paramount importance to take appropriate management measures.

\subsubsection{Chemical Control}

Insecticide applications directed against grape berry moth aid in controlling GFB. However, where a history of damage is known, targeted adulticides may be needed in early season. The pyrethroids fenpropathrin and beta-cyfluthrin and the carbamate carbaryl have provided very good control of GFB (Lockwood et al. 2010). Pyrethroids are very damaging to populations of natural enemies. This undesirable effect may be less pronounced at the bud swell stage than in the summer. Although phosmet is effective, a recent lengthening of the restricted entry interval in the US to 14 days has made it impractical for many growers. In India, carbaryl and monocrotophos provided good control of another flea beetle attacking grapevines, Scelodonta strigicollis Mots (Rao et al. 1983). However, larvae of this species are found in the soil rather than being foliar feeders (Rao et al. 1984).

\subsection{Grape Rootworm}

\subsubsection{Appearance}

The adult grape rootworm (GRW), F. viticida (Chrysomelidae), is a chestnut brown beetle about $6 \mathrm{~mm}$ long, covered with tiny yellow-white hairs (Fig. 17.6). Creamywhite egg clusters of 20-30 eggs are laid on canes or under loose bark. Larvae are white with a brown head capsule. 


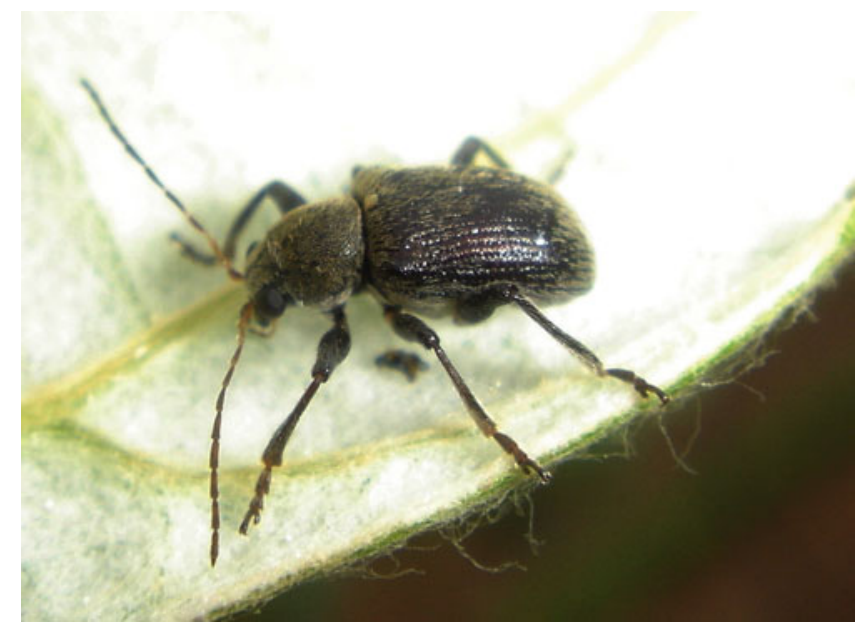

Fig. 17.6 Grape rootworm adult

\subsubsection{Biology}

Grape rootworm was earlier reported as the most destructive grape pest in the Chautauqua-Erie grape region in New York State (Hartzell 1918), and caused the beginning of entomological research in that region (Jubb 1977). Egg clusters of 20-30 eggs are laid on canes or under loose bark, averaging about 100 eggs per female. Eggs hatch in 1-2 weeks and larvae drop to the ground, enter the soil, and feed on grape roots until cold weather. Overwintering takes place among the roots, at depths of 1-2 cm to more than $50 \mathrm{~cm}$. In spring, feeding on roots is resumed. Pupation cells are formed close to the surface, usually $40-60 \mathrm{~cm}$ from vine bases, about the time of grape bloom. Adults appear about 2 weeks later. The grape rootworm has been most severe in the Chautauqua and Lake Erie regions. An effect on yield is difficult to quantify. Numbers of eggs deposited are the best reflection of feeding intensity. Hartzell (1918) recommended that if beetles become a problem, a spray should be applied within a week of beetles becoming active, repeating 10 days later. If populations are high, pesticide applications are recommended the day the adults appear (Hartzell 1918). A related species, Fidia longipes Melsheimer, was reported to have replaced GRW as a pest in Arkansas (Isely 1930).

\subsubsection{Importance of Injury}

Foliar injury is caused by adult feeding. Adults feed on foliage for a month or more, making chain-like feeding marks (Fig. 17.7) similar to those made by larval grape flea beetles. Larvae consume smaller roots and eat pits into larger ones. Root injury 


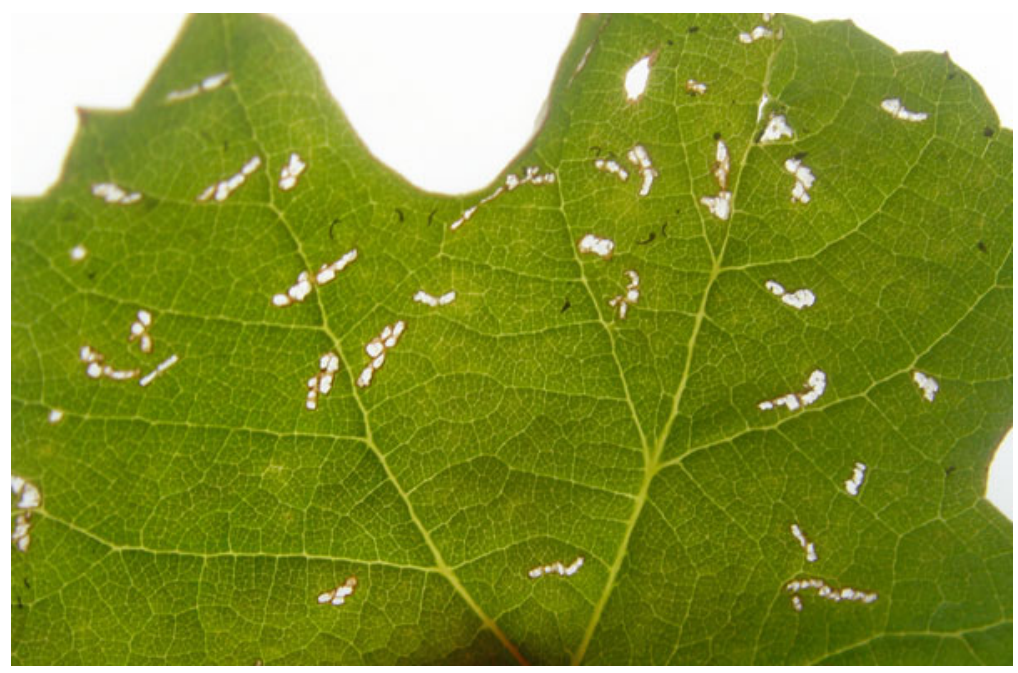

Fig. 17.7 Adult grape rootworm feeding injury to grape foliage

has a much greater impact on the vine than the foliar feeding of adults. As a result of grape rootworm larval infestation on roots, vines become unthrifty, yield is reduced, and in cases of continued high infestation over several years, vine death may occur. Root damage by grape rootworm will be compounded by planting in poor soil.

\subsubsection{Biological Control}

No information is available on biological control of GRW.

\subsubsection{Cultural Control}

Until adults emerge in late June, intensive shallow cultivation of soil may destroy pupae. If an infested vineyard is removed and planted immediately back to grapevines, GRW that had remained in the soil can concentrate onto the young poorly developed root systems and create an immediate risk in the young vineyard.

\subsubsection{Chemical Control}

Few chemical control studies have been conducted because of the relatively low importance of this insect in most areas. Carbaryl is a standard recommendation (Weigle et al. 2010), targeted at adults soon after they become active, and before 
egg-laying begins. Early sprays of some materials directed against grape berry moth not selective for Lepidoptera (e.g., carbaryl, phosmet, fenpropathrin, cyfluthrin, beta-cyfluthrin, bifenthrin, methomyl, or diazinon) may provide control of GRW (Bordelon et al. 2011).

\subsection{Conclusion}

Several coleopteran foliar feeders are associated with grape in eastern North America. The most important of these is the JB, often responsible for extensive defoliation. This defoliation is very damaging to young vines. Mature vines can tolerate substantial foliar feeding by JB without affecting fruit yield or quality. Green June beetle causes similar foliar injury. The other species (grape flea beetle, rose chafer, and grape rootworm) cause minor injury to foliage but cause more important injury on other plant parts (expanding primary buds, young clusters, and roots respectively).

\section{References}

Adler VE, Jacobson M (1971) Electroantennogram responses of adult male and female Japanese beetles to their extracts. J Econ Entomol 64:1561-1562

Allsopp PG, Klein MG, McCoy EL (1992a) Effect of soil moisture and soil texture on oviposition by Japanese beetle and rose chafer (Coleoptera: Scarabaeidae). J Econ Entomol 85:2194-2200

Allsopp PG, Ladd TL, Klein MG (1992b) Sample sizes and distributions of Japanese beetles (Coleoptera: Scarabaeidae) captured in lure traps. J Econ Entomol 85:1797-1801

Alm SR, Yeh T, Hanula JL, Georgis R (1992) Biological control of Japanese, oriental, and black turfgrass Ataenius beetle (Coleoptera: Scarabaeidae) larvae with entomopathogenic nematodes (Nematoda: Steinernematidae, Heterorhabditidae). J Econ Entomol 85:1660-1665

Alm SR, Yeh T, Dawson CG, Klein MG (1996) Evaluation of trapped beetle repellency, trap height, and string pheromone dispensers on Japanese beetle captures (Coleoptera: Scarabaeidae). Environ Entomol 25:1274-1278

Ando Y (1986) Seasonal prevalence and outbreaks of the Japanese beetle, Popillia japonica Newman (Coleoptera: Scarabaeidae). Jpn J Appl Entomol Zool 30:111-116

Andreadis TG, Hanula JL (1987) Ultrastructural study and description of Ovavesicula popilliae n.g., n.sp. (Microsporida: Pleistophoridae) from the Japanese beetle, Popillia japonica (Coleoptera: Scarabaeidae). J Protozool 34:15-21

Barrows EM, Gordh G (1978) Sexual behavior in the Japanese beetle, Popillia japonica, and comparative notes on sexual behavior of other scarabs (Coleoptera: Scarabaeidae). Behav Biol 23: 341-354

Baumler RE, Potter DA (2007) Knockdown, residual, and antifeedant activity of pyrethroids and home landscape bioinsecticides against Japanese beetles (Coleoptera: Scarabaeidae) on linden foliage. J Econ Entomol 100:451-458

Bohlen PJ, Barrett GW (1990) Dispersal of the Japanese beetle (Coleoptera: Scarabaeidae) in strip-cropped soybean agroecosystems. Environ Entomol 19:955-960

Bordelon B, Ellis M, Welty C (2011) 2011 Midwest small fruit and grape spray guide. Purdue University, Lafayette

Boucher TJ (1986) Japanese beetle Popillia japonica Newman: foliar feeding on wine grapes in Virginia. Virginia Polytechnic Institute and State University, Blacksburg 
Boucher TJ, Pfeiffer DG (1989) Influence of Japanese beetle (Coleoptera: Scarabaeidae) foliar feeding on 'Seyval Blanc' grapevines in Virginia. J Econ Entomol 82:220-225

Boucher TJ, Pfeiffer DG, Barden JA, Williams JM (1987) Effects of simulated insect injury on net photosynthesis of potted grapevines. Hortscience 22:927-928

Breen JP (1994) Acremonium endophyte interactions with enhanced plant resistance to insects. Annu Rev Entomol 39:401-423

Britton WE, Johnson JP (1938) The Japanese beetle in Connecticut. Conn Agric Exp Stn Bull 411:455-486

Cappaert DL, Smitley DR (2002) Parasitoids and pathogens of Japanese beetle (Coleoptera: Scarabaeidae) in southern Michigan. Environ Entomol 31:573-580

CDMS (2010) Surround WP crop protectant label. http://www.cdms.net/LabelsMsds/LMDefault. aspx?manuf $=145 \& \mathrm{t}=$

Chittenden FH, Fink DE (1922) The green June beetle. U S Dep Agric Bull 891:1-52

Chittenden FH, Quaintance AL (1916) The rose-chafer: a destructive garden and vineyard pest. U S Dep Agric Farm Bull 721:1-8

Cowles RS, Villani MG (1994) Soil interactions with chemical insecticides and nematodes used for control of Japanese beetle (Coleoptera: Scarabaeidae) larvae. J Econ Entomol 87:1014-1021

Cowles RS, Alm SR, Villani MG (1999) Selective toxicity of halofenozide to exotic white grubs (Coleoptera: Scarabaeidae). J Econ Entomol 92:427-434

Domek JM, Johnson DT (1987) Evidence of a sex pheromone in the green June beetle, Cotinus nitida (Coleoptera: Scarabaeidae). J Entomol Sci 22:264-267

Domek JM, Johnson DT (1988) Demonstration of semiochemically induced aggregation in the green June beetle, Cotinis nitida (L.) (Coleoptera: Scarabaeidae). Environ Entomol 17:147-149

Domek JM, Johnson DT (1990) Inhibition of aggregation behavior in the green June beetle (Coleoptera: Scarabaeidae) by antibiotic treatment of food substrate. Environ Entomol 19: 995-1000

Doolittle RE, Tumlinson JH, Proveaux AT, Heath RR (1980) Synthesis of the sex pheromone of the Japanese beetle. J Chem Ecol 6:473-483

Downing AS (1994) Effect of irrigation and spray volume on efficacy of entomopathogenic nematodes (Rhabditida: Heterorhabditidae) against white grubs (Coleoptera: Scarabaeidae). J Econ Entomol 87:643-646

Dunbar DM, Beard RL (1975) Present status of milky disease of Japanese and oriental beetles in Connecticut. J Econ Entomol 68:453-457

Dutky SR, Gooden EL (1952) Coxiella popilliae, n. sp., a rickettsia causing blue disease of Japanese beetle larvae. J Bacteriol 63:743-750

Fleming WE (1968) Biological control of the Japanese beetle. U S Dep Agric Tech Bull 1383:1-78

Fleming WE (1970) The Japanese beetle in the United States. U S Dep Agric Agric Handb 236:1-30

Fleming WE (1972) Biology of the Japanese beetle. U S Dep Agric Tech Bull 1449:1-129

Gaugler R, Campbell JF (1991) Selection for enhanced host-finding of scarab larvae (Coleoptera: Scarabaeidae) in an entomopathogenic nematode. Environ Entomol 20:700-706

Gaugler R, Campbell J, Selvan M, Lewis E (1992) Large-scale inoculative releases of the entomopathogen Steinernema glaseri: assessment 50 years later. Biol Control 2:181-187

Gaugler R, Wang Y, Campbell J (1994) Aggressive and evasive behaviors in Popillia japonica (Coleoptera: Scarabaeidae) larvae: defenses against entomopathogenic nematode attack. J Invertebr Pathol 64:193-199

Georgis R, Gaugler R (1991) Predictability in biological control using entomopathogenic nematodes. J Econ Entomol 84:713-720

Goonewardene HF, Townshend BG, Bingham RG, Borton R (1973) Improved technique for field use of female Japanese beetles as lures. J Econ Entomol 66:396-397

Gordon CF, Potter DA (1986) Japanese beetle (Coleoptera: Scarabaeidae) traps: evaluation of single and multiple arrangements for reducing defoliation in urban landscape. J Econ Entomol 79:1381-1384

Gu S, Pomper GW (2008) Grape cultivar feeding preference of adult Japanese beetles. Hortscience 43:196-199 
Hamilton RM, Foster RE, Gibb TJ, Sadof CS, Holland JD, Engel BA (2007) Distribution and dynamics of Japanese beetles along the Indianapolis airport perimeter and the influence of land use on trap catch. Environ Entomol 36:287-296

Hammons DL, Kurtural SK, Potter DA (2008) Japanese beetles facilitate feeding by green June beetles (Coleoptera: Scarabaeidae) on ripening grapes. Environ Entomol 37:608-614

Hammons DL, Kurtural SK, Potter DA (2010) Impact of insecticide-manipulated defoliation by Japanese beetle (Popillia japonica) on grapevines from vineyard establishment through production. Pest Manag Sci 66:565-571

Hanula JL (1990) Epizootiological investigations of the microsporidium Ovavesicula popilliae and bacterium Bacillus popilliae in field populations of the Japanese beetle (Coleoptera: Scarabaeidae). Environ Entomol 19:1552-1557

Hanula JL, Andreadis TG (1988) Parasitic microorganisms of Japanese beetle (Coleoptera: Scarabaeidae) and associated scarab larvae in Connecticut soils. Environ Entomol 17: 709-714

Hartzell FZ (1918) Experiments for the control of the grape root-worm. N Y Agric Exp Stn Bull 453:255-332

Hays J, Clopton RE, Cappaert DL, Smitley DR (2004) Revision of the genus Stictospora and description of Stictospora villani, n. sp. (Apicomplexa: Eugregarinida: Actinocephalidae) from larvae of the Japanese beetle, Popillia japonica (Coleoptera: Scarabaeidae), in Michigan. J Parasitol 90:1450-1456

Heath JJ, Williams RN, Phelan PL (2001) High light intensity: a critical factor in the wind-tunnel flight of two scarabs, the rose chafer and Japanese beetle. J Chem Ecol 27:419-429

Held DW, Potter DA (2004) Floral affinity and benefits of dietary mixing with flowers for a polyphagous scarab, Popillia japonica Newman. Oecologia 140:312-320

Held DW, Eaton T, Potter DA (2001) Potential for habituation to a neem-based feeding deterrent to Japanese beetles, Popillia japonica. Entomol Exp Appl 101:25-32

Held DW, Gonsiska P, Potter DA (2003) Evaluating companion planting and non-host masking odors for protecting roses from the Japanese beetle (Coleoptera: Scarabaeidae). J Econ Entomol 96:81-87

Isely D (1930) Fidia longipes as a grape pest. J Econ Entomol 23:95-97

Iwabuchi K, Takahashi J (1983) Aggregative distribution of the Japanese beetle, Popillia japonica Newman (Coleoptera: Scarabaeidae), and the role of former occupants in the formation of an aggregation. Appl Entomol Zool 18:324-329

Johnson DT, Lewis BA (2008) Efficacy of feeding on insecticides and dosage response of contact insecticides against green June beetle, 2007. Arthropod Manag Tests 33:C10

Johnson DT, Lewis BA (2009) Efficacy of insecticides against green June beetle, 2008. Arthropod Manag Tests 34:C13

Johnson DT, Vishniac HS (1991) The role of Trichosporon cutaneum in eliciting aggregation behavior in Cotinis nitida (Coleoptera: Scarabaeidae). Environ Entomol 20:15-21

Johnson DT, Lewis BA, Bryant RJ, Liyanage R, Lay JO, Pszczolkowski MA (2009) Attractants for the green June beetle (Coleoptera: Scarabaeidae). J Econ Entomol 102:2224-2232

Jubb GL (1977) History of entomological research on grapes and other crops in Erie County, Pennsylvania. Melsheimer Entomol Ser 22:7-11

Keathley CP, Potter DA (2008) Quantitative resistance traits and suitability of woody plant species for a polyphagous scarab, Popillia japonica Newman. Environ Entomol 37:1548-1557

King JL (1931) The present status of the established parasites of Popillia japonica Newman. J Econ Entomol 24:453-462

Klein MG, Edwards DC (1989) Captures of Popillia lewisi (Coleoptera: Scarabaeidae) and other scarabs on Okinawa with Japanese beetle lures. J Econ Entomol 82:101-103

Klein MG, Lawrence KO, Ladd TL (1973) Japanese beetles: shielded traps to increase captures. J Econ Entomol 66:562-563

Klein MG, Tumlinson JH, Ladd TL, Doolittle RE (1981) Japanese beetle (Coleoptera: Scarabaeidae): response to synthetic sex attractant plus phenethyl propionate: eugenol. J Chem Ecol 7:1-7 
Klostermeyer LE (1985) Japanese beetle (Coleoptera: Scarabaeidae) traps: comparison of commercial and homemade traps. J Econ Entomol 78:454-459

Koppenhöfer AM, Fuzy EM (2004) Effect of white grub developmental stage on susceptibility to entomopathogenic nematodes. J Econ Entomol 97:1842-1849

Koppenhöfer AM, Kaya HK (1998) Synergism of imidacloprid and an entomopathogenic nematode: a novel approach to white grub (Coleoptera: Scarabaeidae) control in turfgrass. J Econ Entomol 91:618-623

Koppenhöfer AM, Wilson M, Brown I, Kaya HK, Gaugler R (2000) Biological control agents for white grubs (Coleoptera: Scarabaeidae) in anticipation of the establishment of the Japanese beetle in California. J Econ Entomol 93:71-80

Kruse KC, Switzer PV (2007) Physical contests for females in the Japanese beetle, Popillia japonica. J Insect Sci 7:1-10

Ladd TL (1966) Egg viability and longevity of Japanese beetles treated with tepa, aphodate, and metepa. J Econ Entomol 59:422-425

Ladd TL (1970) Sex attraction in the Japanese beetle. J Econ Entomol 63:905-908

Ladd TL (1986) Enhancement of lures for Japanese beetles (Coleoptera: Scarabaeidae) by eugenol and Japonilure. J Econ Entomol 79:405-409

Ladd TL (1987) Influence of food, age, and mating on production of fertile eggs by Japanese beetles (Coleoptera: Scarabaeidae). J Econ Entomol 80:93-95

Ladd TL, Jacobson M, Buriff CR (1978) Japanese beetles: extracts from neem tree seeds as feeding deterrents. J Econ Entomol 71:810-813

Ladd TL, Klein MG, Tumlinson JH (1981) Phenethyl propionate + eugenol + geraniol (3:7:3) and Japonilure: a highly effective joint lure for Japanese beetles. J Econ Entomol 74:665-667

Ladd TL, Warthen JD, Klein MG (1984) Japanese beetle (Coleoptera: Scarabaeidae): the effects of azadirachtin on the growth and development of the immature forms. J Econ Entomol 77:903-905

Lalancette N, Belding RD, Shearer PW, Frecon JL, Tietjen WH (2005) Evaluation of hydrophobic and hydrophilic kaolin particle films for peach crop, arthropod and disease management. Pest Manag Sci 61:25-39

Landolt PJ (1990) Trapping the green June beetle (Coleoptera: Scarabaeidae) with isopropanol. Fla Entomol 73:328-330

Langford GS, Cory EN (1948) Host preference in Japanese beetles with special reference to grape and apple. J Econ Entomol 41:823-824

Leal WS (1998) Chemical ecology of phytophagous scarab beetles. Annu Rev Entomol 43:39-61

Lockwood D, Sutton T, Burrack H, Pfeiffer D, Mitchem W, Bellinger B et al (2010) southeast regional bunch grape integrated management guide. Southern Region Small Fruit Consortium, Raleigh

López R, Potter DA (2000) Ant predation on eggs and larvae of the black cutworm (Lepidoptera: Noctuidae) and Japanese beetle (Coleoptera: Scarabaeidae) in turfgrass. Environ Entomol 29:116-125

Loughrin JH, Potter DA, Hamilton-Kemp TR (1995) Volatile compounds induced by herbivory act as aggregation kairomones for the Japanese beetle (Popillia japonica Newman). J Chem Ecol 21:1457-1467

Loughrin JH, Potter DA, Hamilton-Kemp TR, Byers ME (1996) Role of feeding-induced plant volatiles in aggregative behavior of the Japanese beetle (Coleoptera: Scarabaeidae). Environ Entomol 25:1188-1191

Mannion CM, Winkler HE, Shapiro DI, Gibb TJ (2000) Interaction between halofenozide and the entomopathogenic nematode Heterorhabditis marelatus for control of Japanese beetle (Coleoptera: Scarabaeidae) larvae. J Econ Entomol 93:48-53

Mannion CM, McLane W, Klein MG, Moyseenko J, Oliver JB, Cowan DC (2001) Management of early-instar Japanese beetle (Coleoptera: Scarabaeidae) in field-grown nursery crops. J Econ Entomol 94:1151-1161

Maxey LM, Laub CS, Mays RS, Pfeiffer DG (2008) Japanese beetle (Popillia japonica) control and varietal comparisons in primocane-bearing brambles. In: Proceedings of the 84th Cumberland-Shenandoah fruit workers conference 84:66-71 
Maxey L, Laub C, Pfeiffer DG (2009) Effects of geranium exposure on Japanese beetle (Popillia japonica) feeding on primocane-bearing raspberries. In: Proceedings of the 85th CumberlandShenandoah fruit workers conference 85:26-30

McCleod MJ, Williams RN (1990) Life history and vineyard damage by rose chafer. Vinifera Wine Growers J 17:25-27

Mercader RJ, Isaacs R (2003) Damage potential of rose chafer and Japanese beetle (Coleoptera: Scarabaeidae) in Michigan vineyards. Gt Lakes Entomol 36:166-178

Moore AR, Cole WH (1921) The response of Popillia japonica to light and the Weber-Fechner law. J Gen Physiol 3:331-335

Niemczyk HD, Lawrence KO (1973) Japanese beetle: evidence of resistance to cyclodiene insecticides in larvae and adults in Ohio. J Econ Entomol 66:520-521

Oliver JB, Mannion CM, Klein MG, Moyseenko JJ, Bishop B (2005) Effect of insecticides on Tiphia vernalis (Hymenoptera: Tiphiidae) oviposition and survival of progeny to cocoon stage when parasitizing Popillia japonica (Coleoptera: Scarabaeidae) larvae. J Econ Entomol 98:694-703

Oliver JB, Reding ME, Moyseenko JJ, Klein MG, Mannion CM, Bishop B (2006) Survival of adult Tiphia vernalis (Hymenoptera: Tiphiidae) after insecticide, fungicide, and herbicide exposure in laboratory bioassays. J Econ Entomol 99:288-294

Patton CN (1956) Observations on the mating behavior of the green June beetle, Cotinus nitida (Linn.). Fla Entomol 39:95

Pfeiffer DG, Boucher TJ, Lachance MW, Killian JC (1990) Entomological research in Virginia (USA) vineyards. In: Bostanian NJ, Wilson LT, Dennehy TJ (eds) Monitoring and integrated management of arthropod pests of small fruit crops. Intercept, Andover, pp 45-61

Potter DA, Held DW (1999) Absence of food-aversion learning by a polyphagous scarab, Popillia japonica, following intoxication by geranium, Pelargonium x hortorum. Entomol Exp Appl 91:83-88

Potter DA, Held DW (2002) Biology and management of the Japanese beetle. Annu Rev Entomol 47:175-205

Potter DA, Patterson CG, Redmond CT (1992) Influence of turfgrass species and tall fescue endophyte on feeding ecology of Japanese beetle and southern masked chafer grubs (Coleoptera: Scarabaeidae). J Econ Entomol 85:900-909

Potter DA, Powell AJ, Spicer PG, Williams DW (1996) Cultural practices affect root-feeding white grubs (Coleoptera: Scarabaeidae) in turfgrass. J Econ Entomol 89:156-164

Ramoutar D, Legrand A (2007) Survey of Tiphia vernalis (Hymenoptera: Tiphiidae), a parasitoid wasp of Popillia japonica (Coleoptera: Scarabaeidae), in Connecticut. Fla Entomol 90:780-782

Rao RV, Lakshminarayana K, Subbbaratnam GV (1983) Residual toxicity of certain insecticides to grapevine flea beetle. Entomon 8:395-396

Rao RV, Lakshminarayana K, Subbaratnam GV (1984) Seasonal occurrence of grapevine flea beetle, Scelodonta strigicollis (Mots) around Hyderabad. Entomon 9:59-60

Reed DK, Lee MH, Kun SH, Klein MG (1991) Attraction of scarab beetle populations (Coleoptera: Scarabaeidae) to Japanese beetle lures in the Republic of Korea. Agric Ecosyst Environ 36: $163-174$

Régnière J, Brooks WM (1978) Entomogenous microorganisms associated with the Japanese beetle, Popillia japonica, in eastern North Carolina. J Invertebr Pathol 32:226-228

Régnière J, Rabb RL, Stinner RE (1983) Popillia japonica (Coleoptera: Scarabaeidae): distribution and movement of the adults in heterogeneous environments. Can Entomol 115:287-294

Rogers ME, Potter DA (2002) Kairomones from scarabaeid grubs and their frass as cues in belowground host location by the parasitoids Tiphia vernalis and Tiphia pygidialis. Entomol Exp Appl 102:307-314

Rowe WJ II, Potter DA (1996) Vertical stratification of feeding by Japanese beetles within linden tree canopies: selective foraging or height per se? Oecologia 108:459-466

Schroeder PV, Villani MG, Ferguson CS, Nyrop JP, Shields EJ (1993) Behavioral interactions between Japanese beetle (Coleoptera: Scarabaeidae) grubs and an entomopathogenic nematode (Nematoda: Heterorhabditidae) within turf microcosms. Environ Entomol 22:595-600 
Stahly DP, Klein MG (1992) Problems with in vitro production of spores of Bacillus popilliae for use in biological control of the Japanese beetle. J Invertebr Pathol 60:283-291

Szendrei Z, Isaacs R (2006) Ground covers influence the abundance and behaviour of Japanese beetle in blueberry fields. Environ Entomol 35:789-796

Szendrei Z, Mallampalli N, Isaacs R (2005) Effect of tillage on abundance of Japanese beetle, Popillia japonica Newman (Col., Scarabaeidae), larvae and adults in highbush blueberry fields. J Appl Entomol 129:258-264

Vishniac HS, Johnson DT (1990) Development of a yeast flora in the adult green June beetle (Cotinus nitida, Scarabaeidae). Mycologia 82:471-479

Vittum PJ (1986) Biology of the Japanese beetle (Coleoptera: Scarabaeidae) in eastern Massachusetts. J Econ Entomol 79:387-391

Vitullo JM, Sadof CS (2007a) Effects of pesticide applications and cultural controls on efficacy of control for adult Japanese beetles (Coleoptera: Scarabaeidae) on roses. J Econ Entomol 100: 95-102

Vitullo JM, Sadof CS (2007b) Efficacy of soil and foliar-applied azadirachtin in combination with and in comparison to soil-applied imidacloprid and foliar-applied carbaryl against Japanese beetles on roses. HortTechnology 17:316-321

Wang Y, Gaugler R (1998) Host and penetration site location by entomopathogenic nematodes against Japanese beetle larvae. J Invertebr Pathol 72:313-318

Wang Y, Gaugler R, Cui L (1994) Variations in immune response of Popillia japonica and Acheta domesticus to Heterorhabditis bacteriophora and Steinernema species. J Nematol 26:11-18

Wang Y, Campbell JF, Gaugler R (1995) Infection of entomopathogenic nematodes Steinernema glaseri and Heterorhabditis bacteriophora against Popillia japonica (Coleoptera: Scarabaeidae) larvae. J Invertebr Pathol 66:178-184

Weigle TH, Muza AJ, Gardner R, Helms M, Bates TR, Reisch BI et al (2010) 2010 New York and Pennsylvania pest management guidelines for grapes. http://www.ipmguidelines.org/grapes

Williams RN, Fickle DS (2007) Chemical evaluations for control of Japanese beetle on grapes, 2006. Arthropod Manag Tests 32:C12

Williams RN, Fickle DS (2008) Chemical evaluations for control of Japanese beetle on grapes, 2007. Arthropod Manag Tests 33:C27

Williams RN, Miller KV (1982) Field assay to determine attractiveness of various aromatic compounds to rose chafer adults. J Econ Entomol 75:196-198

Williams RN, McGovern TP, Klein MG (1982) Evaluation of aromatic compounds and virgin females as attractants for rose chafer. Res Circ Ohio Agric Res Dev Cent 272:38-40

Wise JC, Vandervoort C, Isaacs R (2007) Lethal and sublethal activities of imidacloprid contribute to control of adult Japanese beetle in blueberries. J Econ Entomol 100:1596-1603

Wise JC, Poppen RV, Isaacs R (2009) Grape berry moth control, 2008. Arthropod Manag Tests 34: $\mathrm{C} 21$

Wood TN, Richardson M, Potter DA, Johnson DT, Wiedenmann RN, Steinkraus DC (2009) Ovipositional preferences of the Japanese beetle (Coleoptera: Scarabaeidae) among warm- and cool-season turfgrass species. J Econ Entomol 102:2192-2197

Wylie WD (1969) Attractants for green June beetle adults. Ark Farm Res 18:11

Zenger JT, Gibb TJ (2001a) Identification and impact of egg predators of Cyclocephala lurida Bland and Popillia japonica Newman (Coleoptera: Scarabaeidae) in turfgrass. Environ Entomol 30:425-430

Zenger JT, Gibb TJ (2001b) Impact of four insecticides on Japanese beetle (Coleoptera: Scarabaeidae) egg predators and white grubs in turfgrass. J Econ Entomol 94:145-149 